Background to Modern Science

Ten Lectures at Cambridge arranged by the History of Science Committee, 1936, by F. M. Cornford, Sir W. Dampier, Lord Rutherford, W. L. Bragg, F. W. Aston, Sir A. S. Eddington, J. A. Ryle, G. H. F. Nuttall, R. C. Punnett, J. B. S. Haldane. Edited by Joseph Needham and Walter Pagel. (Cambridge Library of Modern Science.) Pp. xii +243. (Cambridge: At the University Press, 1938.) 7s. 6d. net.

THE ten lectures which make up the present 1 volume were delivered in Cambridge during 1936, under the auspices of the then newly formed History of Science Committee, and it is not surprising to learn from the preface that they were attended by crowded and enthusiastic audiences. A glance at the list of authors will show that the Committee was fortunate in being able to enlist the services of a most distinguished team of lecturers, and as the volume itself shows, it was equally fortunate in being able to secure the manuscripts of the lectures in a form suitable for publication.

Apart from introductory lectures on Greek natural philosophy and on the period stretching from Aristotle to Galileo, the remainder of the volume consists of accounts of the progress, during the past forty years, of some of the more active branches of science. Radioactivity, crystal physics, atomic theory, astronomy, pathology, parasitology, evolution theory and genetics have been selected as representing what the dust cover describes as "the cutting edge of human scientific activity". To praise the work of the distinguished authors would be both superfluous and impertinent. Within the very brief space at his disposal-some twenty-four pages - each author has succeeded in giving a vivid, personal, and authoritative 'eye-witness's account' of the progress on his own section of the scientific front. Perhaps some future volume in this excellent library will give us a co-ordinated account of the campaign as a whole.

$$
\text { J. A. C. }
$$

\section{The Atlas of To-day and To-morrow}

By Alexander Radó. Pp. ix +198. (London : Victor Gollancz, Ltd., 1938.) 10s. 6d. net.

$\Delta \mathrm{S}$, with the advance of science, the world A shrinks, human geography grows in importance. Scarcely a generation passes but now States are created or the boundaries of old ones are revised. The present volume is admirable in scope and execu. tion. Its aim is not to dwell upon the more or less static geographical features which find their place in the usual type of atlas, but to provide a cartographic record of that bewildering mass of political and economic problems which have such an important bearing upon the future of mankind.

A more accurate title would be "The Atlas of Yesterday and To-day". Starting from 1875 the authors picture the progressive division of the world by the great powers, the building up of colonial empires, the struggle for world markets and the control of communications, concluding with a brief summary of significant differences in religion, race, nationality and forms of government. The statistical tables are numerous, concise and instructive, but the reader is left to discover for himself which figures are well grounded and which, at best, can only be rough estimates. In the next edition, to which we may look forward confidently, the use of a comma both as comma and as decimal point (for example, in Table 4) should be avoided, and a serious error throughout the first column of figures in Table 7 should be corrected.

\section{Library Guide for the Chemist}

By Prof. Byron A. Soule. (International Chemical Series.) Pp. xiii +302. (New York and London : McGraw-Hill Book Co., Inc., 1938.) $15 s$.

7 HERE are published every twelve months about fifteen hundred books, forty thousand articles and 20,000 patents of chemical interest; this flood is increasing at the rate of 6 per cent per annum. The chemist, whether he be research worker or engaged in industry, must be in touch with some portion of this literature if he is to avoid repeating work which has been done elsewhere, whilst there are many others who seek to locate chemical information beyond the purely obvious. The research student gets some kind of training in the use of a chemical library, but it is not always easy to know where to look; moreover, critical judgment as to the quality of the work consulted is an important element for success. It is valuable therefore to have a book entirely devoted to acting as a guide to this enormous literature. That before us is well done, and though of trans-Atlantic origin it will be equally serviceable in a British or European laboratory. A corollary of such work is the existence of really good libraries. Chemists are strangely lacking in a proper sense of co-operative effort and it is a stigma that the library of the Chemical Society, which is still the best in the world, is still inadequately housed and supported.

\section{The Elements of Quantum Mechanics}

By Dr. Saul Dushman. Pp. xiii +452. (New York : John Wiley and Sons, Ine.; London : Chapman and Hall, Ltd., 1938.) 25s. net.

$\mathrm{D}^{\mathrm{n}}$ R. DUSHMAN'S admirable book is the outcome of a series of lectures on quantum mechanics delivered by him at the Ohio State University. They were addressed to students who had not received "any intensive training in mathematics beyond calculus". This being so, the development of the various theses is somewhat leisurely but, from the pædagogic point of view, is all the better on that account. The author has selected his topics for discussion with discretion and presents them most skilfully. He deals in turn with the Schrödinger equation, potential barriers, the linear harmonic oscillator, the rigid rotator, the hydrogen and helium atoms, the hydrogen molecule, valence bonds, and the theory of radiation.

The treatment is as elementary as may be; the exposition is remarkably clear, and the book may be warmly commended as an introduction to more advanced treatises.
A. F. 